\title{
Seroprevelensi Virus Avian Influenza SubTipe H5N1 Pada Unggas Domestik Peliharaan Masyarakat di Kawasan Cagar Alam Pulau Dua Serang Provinsi Banten
}

\author{
Agrydzadana Frisa $^{1}$, Dewi Elfidasari ${ }^{2}$, Sri Murtini $^{3}$ \\ ${ }^{1,2}$ Program Studi Biologi, Fakultas Sains dan Teknologi Universitas Al Azhar Indonesia \\ ${ }^{3}$ Departemen Ilmu Penyakit Hewan dan Kesehatan Masyarakat Veteriner, Fakultas Kedokteran \\ Hewan, Institut Pertanian Bogor
}

Penulis untuk Korespondensi/E-mail: d_elfidasari@uai.ac.id

Abstrak - Unggas domestik di sekitar kawasan Cagar Alam Pulau Dua (CAPD) banyak berinteraksi dengan burung air liar yang terinfeksi virus H5N1. Oleh karena itu perlu diperoleh informasi terkait keberadaan Virus AI pada unggas domestik tersebut. Penelitian ini bertujuan untuk mengetahui prevalensi serologi Avian Influenza (AI) H5N1 pada unggas peliharaan masyarakat yang dipelihara dengan sistem backyard di sekitar kawasan CAPD. Pengamatan terhadap habitat dan perilaku bebek, ayam dan mentok dilakukan untuk menganalisa adanya interaksi dengan burung air liar di kawasan CAPD. Sebanyak 49 sampel serum yang terdiri dari 15 sampel serum bebek, 14 sampel serum mentok dan 20 serum ayam diperiksa keberadaan antibodi terhadap AI subtipe H5N1 melalui uji hambatan aglutinasi (Haemaglutination Inhibition). Hasil pengamatan menunjukkan presentase seroprevalensi mencapai $100 \%$ dengan nilai Geometric Mean Titer sampel yang diperiksa sebesar $2^{7,9}$ untuk mentok, $2^{4,6}$ untuk bebek dan $2^{77}$ untuk ayam. Terdapatnya antibodi membuktikan unggas peliharaan masyarakat di kawasan CAPD pernah terpapar virus AI subtipe H5N1.

Kata Kunci - Avian Influenza, CAPD, Unggas Domestik, Haemaglutination Inhibition

Abstract - Domestic birds around Pulau Dua Nature Reserve area (CAPD) interact with wild water birds infected with H5N1 virus. Therefore it is necessary to obtain information related to the presence of AI virus in domestic poultry. This study aims to determine the prevalence of Avian Influenza serology (AI) H5N1 in community poultry maintained by backyard system around CAPD area. Observation of habitat and duck, chicken and stuck behavior was done to analyze the interaction with wild water birds in CAPD area. A total of 49 serum samples consisting of 15 serum duck samples, 14 serum serum samples and 20 serum chickens examined the presence of antibodies against AI subtypes H5N1 through an agglutination inhibition test (Haemaglutination Inhibition). The observation result shows that seroprevalency percentage reaches $100 \%$ with Geometric Mean Titer value of examined sample is 27,9 for stool, 24,6 for duck and 277 for chicken. The presence of antibodies proves that community poultry in the CAPD region has been exposed to AI virus subtype H5N1.

Keywords - Avian Influenza, CAPD, Unggas Domestik, Haemaglutination Inhibition 


\section{PENDAHULUAN}

$\mathrm{V}$ irus Avian Influenza (VAI) subtipe H5N1 sejak tahun 1959 sudah mulai mewabah di berbagai belahan dunia. Unggas-unggas pada sejumlah negara di benua Asia, Afrika, Amerika, Australia bahkan Eropa dalam kurun waktu yang panjang telah terinfeksi virus AI tersebut sehingga menyebabkan kerugian besar. Virus ini pertama kali menyerang unggas jenis ayam. Pada tahun 1959 dilaporkan bahwa dua kelompok ayam terindikasi terkena virus AI di Skotlandia serta puluhan ribu kalkun ditemukan mati di sekitar Inggris dan Kanada. Wabah inisemakin meluas pada jenis unggas lainnya termasuk angsa, itik, burung puyuh bahkan burung liar (European Commission, 2000).

Tahun 2003 VAI subtipe H5N1 mulai mewabah di Indonesia. Pada tahun 2004, wabah Avian Influenza terjadi di Kabupaten Pekalongan dan Tangerang. Wabah ini menyerang ayam ras petelur dan pedaging, burung puyuh, ayam kampung dan itik. Angka mortalitas dalam kasus ini sangat tinggi yaitu 90\%(Anies, 2005). Berdasarkan data Office International des Epizooties (OIE) tahun 2005, Indonesia termasuk ke dalam negara endemik VAI pada unggas, selain Mesir dan Nigeria (Kamps et al., 2006).

Virus influenza merupakan nama generik virus yang berasal dari keluarga Orthomyxoviridae dan diklasifikasikan dalam tipe A, B atau C berdasarkan perbedaan sifat antigenik dari nucleoprotein dan matrix proteinnya. Virus influenza unggas termasuk tipe A (Kamps et al.,2006). Virus influenza tipe B dan C biasanya menyerang manusia dan babi (Akoso, 2006). Unggas air adalah pembawa (carrier) seluruh virus influenza. Unggas air diduga merupakan reservoir alami untuk semua jenis virus influenza (Webster et al., 1992; Fouchier et al., 2003; Widjaja et al., 2004).

Data kasus Avian Influenza pada unggas yang pernah terjadi di Indonesia, menurut laporan Departemen Pertanian tahun 2004 sejak akhir bulan Agustus 2003 sampai akhir Januari 2004 VAI telah menyebabkan kematian pada unggas sedikitnya 4,7 juta ekor (Winarno 2008). VAI yang tidak menyebabkan penyakit pada reservoir alaminya disebut sebagai Low Pathogenic Avian Infuenza (LPAI). Virus LPAI hanya mengakibatkan penurunan produksi telur yang bersifat ringan dan sementara, atau menurunkan bobot badan pada unggas pedaging (Capua \& Mutinelli 2001). Turunan (strain) virus LPAI dapat ditularkan keunggas yang rentan seperti ayam, mentok dan itik. Saat terjadi penularan yang berulang pada unggas tersebut, virus LPAI dapat beradaptasi dengan inang yang baru dan mengalami mutasi menjadi bentuk sangat patogen berupa Highly Pathogenic Avian Influnza Virus (HPAIV). HPAIV dapat menimbulkan penyakit sistemik ganas dan mematikan secara cepat (Kamps et al., 2006).

Penelitian yang dilakukan tahun 20072011 memberi informasi bahwa burung air di kawasan Cagar Alam Pulau Dua (CAPD) seperti Kowak Malam (Nycticorax nycticorax), Kuntul Besar (Casmerodius albus), Kuntul Sedang (Egretta intermedia), Kuntul Kecil (Egretta garzetta) dan Kuntul Kerbau (Bubulcus ibis) telah terpapar virus AI subtipe H5NI. Unggas peliharaan masyarakat di sekitar kawasan CAPD yang dipelihara dengan sistem pekarangan banyak berinteraksi langsung dengan burung air tersebut. Interaksi terjadi saat unggas dan burung air tersebut mencari makan bersama di sawah atau tambak. Oleh karena itu perludilakukan penelitian uji seroprevalensi virus AI subtipe H5N1 pada unggas peliharaan masyarakat di sekitar kawasan CAPD untuk mengetahui adanya paparan virus AI pada unggas tersebut.

\section{Tujuan Penelitian}

Penelitian ini bertujuan untuk menentukan seroprevalensi virus AI subtipe H5N1 pada unggas peliharaan masyarakat di sekitar kawasan CAPD.

\section{Manfaat Penelitian}

Hasil penelitian ini diharapkan memberikan informasi prevalensi serologis virus AI subtipe 


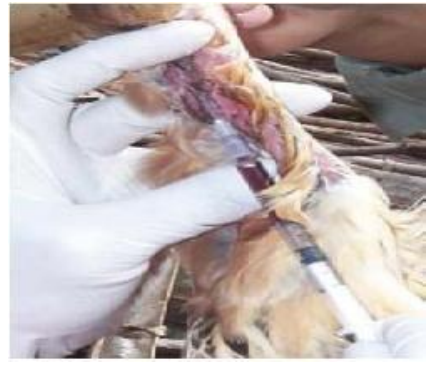

Gambar 1. Pengambilan Sampel Darah (Sumber: Kurniadhi P \& Suparno 2009)

H5N1 pada unggas peliharaan masyarakat yang berada di sekitar kawasan CAPD sehingga dapat dijadikan acuan dalam upaya pencegahan penyebaran virus AI subtipe H5N1 pada unggas peliharaan dan burung liar.

\section{METODOLOGI PENELITIAN}

\section{Lokasi dan Waktu Penelitian}

Objek yang diteliti adalah serum darah unggas domestik (ayam, itik dan mentok) yang dipelihara masyarakat di sekitar kawasan Cagar Alam Pulau Dua (CAPD). Penelitian dilakukan dengan dua tahapan, yaitu tahap penelitian lapangan berupa pengambilan sampel darah unggas peliharaan masyarakat di sekitar kawasan CAPD, dan penelitian laboratorium di Bagian Mikrobiologi Medis Departemen Ilmu Penyakit Hewan dan Kesehatan Mayarakat Veteriner Fakultas Kedokteran Hewan IPB Bogor.

\section{Metode Pengambilan Serum Darah}

Peralatan yang dipergunakan dalam proses pengambilan sampel adalah jarum suntik $1 \mathrm{ml}$, buku panduan lapangan, microtube, masker, label, gunting, kapas, alcohol, cooling box, ice pack dan sarung tangan latek. Pengambilan sampel dilakukan dengan metode menyengaja (Purposive Sampling). Itik, mentok dan ayam peliharaan masyarakat diambil darahnya menggunakan jarum suntik sebanyak $1-1,5 \mathrm{ml}$. Darah berasal dari vena branchialis, setelah diambil darah didiamkan semalaman dalam suhu $4{ }^{\circ} \mathrm{C}$ untuk memisahkan antara serum dan sel darah merah, selanjutnya serum dipisahkan dan dimasukkan dalam mikrotube dan disimpan pada suhu $20^{\circ} \mathrm{C}$ sampai saat pemeriksaan (Gambar 1).

\section{Pembuatan Suspensi Sel Darah Merah (Eritrosit) 1\% \\ Pengujian HA dan HI mikrotitrasi memerlukan suspensi eritrosit dengan konsentrasi $1 \%$. Suspensi eritrosit dengan konsentrasi $1 \%$}

diperoleh dengan mengambil darah ayam melalui vena branchialis dengan menggunakan jarum suntik ukuran $3 \mathrm{ml}$. Darah kemudian dimasukkan ke dalam tabung venoject yang telah diisi antikoagulan Natrium Citrat 3,8\% dengan perbandingan 1:4. Darah disentrifugasi selama 10 menit dengan kecepatan 2000 G. Supernatan dibuang dan sel darah merah yang mengendap dicuci dengan menambahkan larutan PBS. Proses pencucian dilakukan dengan sentrifugasi selama 10 menit dengan kecepatan $2000 \mathrm{G}$ kemudian dibuang supernatannya dan ditambahkan PBS. Proses ini diulang sampai 3 kali. Setelah tiga kali pencucian, didapatkan endapan eritrosit yang merupakan suspensi eritrosit $100 \%$. Suspensi eritrosit $1 \%$ dibuat dengan mengencerkan suspensi eritrosit 100\% menjadi $1 \%$ menggunakan PBS.

\section{Persiapan Virus Standar}

Uji HA dilakukan untuk mendapatkan virus standar 4 HAU. Sebanyak $25 \mu$ PBS dimasukkan ke dalam 12 sumur pada microplate ( $v$ bottom microplate), kemudian setiap sumur pertama ditambahkan $25 \mu 1$ suspensi virus AI. Virus dihomogenkan dengan cara menghisap dan mengeluarkan kembali larutan menggunakan mikropipet minimal 5 kali, kemudian dilakukan pengenceran bertingkat kelipatan dua. Setiap sumur ditambahkan PBS $25 \mu \mathrm{l}$ dan $1 \%$ suspensi sel darah merah sebanyak $25 \mu$, dan diinkubasi selama 20-40 menit. Setelah itu dilakukan pengamatan terhadap titer virusnya. Titer virus yang diperoleh diencerkan sampai titernya mencapai 4 HAU.

\section{Uji Hambatan Hemaglutinasi (HI)}

Uji HI dilakukan menggunakan antigen berupa virus inaktif H5N1 pada titer 4 HAU sebanyak $25 \mu 1$ dan sel darah merah $1 \%$. Sumur 1-12 dari microplate ( $v$ bottom microplate) diisi dengan PBS masingmasing sebanyak $25 \mu$ l. Masing-masing sebanyak $25 \mu$ l sampel serum ditambahkan pada sumur pertama dan dilakukan pengenceran bertingkat kelipatan dua. Kemudian ditambahkan $25 \quad \mu \mathrm{l}$ virus standar (4 HAU) pada semua sumur. 
Setelah dicampur sampai homogen, diinkubasi pada suhu ruang selama 20-40 menit. Kemudian ditambahkan $25 \mu 1$ suspensi sel darah merah $1 \%$ ke dalam setiap sumur uji. Microplate digoyanggoyangkan dan diinkubasi pada suhu ruang selama 60 menit. Sampel dinyatakan positif apabila sel darah merah mengendap. Perhitungan titer HI didapat berdasarkan pengenceran tertinggi serum yang berhasil menetralkan virus ditandai dengan pengendapan sel darah merah (Gambar 2).

Menurut Office International des Epizooties OIE (2009), untuk menggambarkan rata-rata titer antibodi digunakan perhitungan Geometric Mean Titer (GMT) dengan rumus sebagai berikut :

$\log 2$ GMT: $\underline{(\log 2 \mathrm{t} 1)(\mathrm{S} 1)+(\log 2 \mathrm{t} 2)(\mathrm{S} 2)+(\log 2 \mathrm{tn})}$ $\underline{(\mathrm{Sn})} \mathrm{N}$

Keterangan:

$\mathrm{N}=$ Jumlah contoh serum yang diamati

$\mathrm{t}=$ Titer antibodi pada pengenceran tertinggi (yang masih menghambat aglutinasi sel darah merah)

$\mathrm{S}=$ Jumlah contoh serum yang bertiter 1

$\mathrm{N}=$ Titer antibodi pada sampel ke-n

\section{HASIL DAN PEMBAHASAN}

Hasil uji hemaglutination inhibition assay (uji HI) dan nilai seroprevalensi terhadap sampel serum darah unggas domestik (ayam, mentok dan itik) yang diperoleh dari peternakan rumah tangga (pekarangan) di sekitar kawasan Cagar Alam Pulau Dua (CAPD) menunjukkan bahwa ketiga spesies unggas domestik tersebut pernah terpapar virus AI subtipe H5N1. Nilai rataan titer untuk menjadi reservoir yang nyaman bagi tumbuhnya virus. Antara virus dan reservoir terjadi toleransi yang baik, sehingga replikasi atau perbanyakan virus di dalam tubuh unggas dapat terjadi secara efisien (Elfidasari, 2013).

Tabel 1. Hasil uji HI sampel unggas domestik di peternakan rumah tangga di sekitar kawasan Cagar Alam Pulau Dua (CAPD)

\begin{tabular}{|l|c|c|c|}
\hline Spesies & $\sum$ sampel & $\begin{array}{c}\sum \text { Positif }(\%) \\
\text { (Seroprevalensi) }\end{array}$ & $\begin{array}{l}\text { Rataan Titer Antibodi } \\
\text { (GMT) }\end{array}$ \\
\hline Ayam & 20 & 100 & $2^{7,7}$ \\
\hline Mentok & 14 & 100 & $2^{6,9}$ \\
\hline Itik & 15 & 100 & $2^{4,6}$ \\
\hline Total & 49 & 100 & \\
\hline
\end{tabular}

Uji HI dengan hasil positif menandakan adanya antibodi yang menunjukkan telah terjadi infeksi atau paparan virus AI subtipe H5N1 pada tubuh hewan. Antibodi terbentuk sebagai respon keberadaan antigen dan akan bereaksi secara spesifik dengan antigen tersebut melalui protein imunoglobulin. Selain dengan uji HI, keberadaan antibodi spesifik terhadap protein juga dapat dideteksi dengan imunopresipitasi dalam agar dan ELISA (Jin et al., 2004).

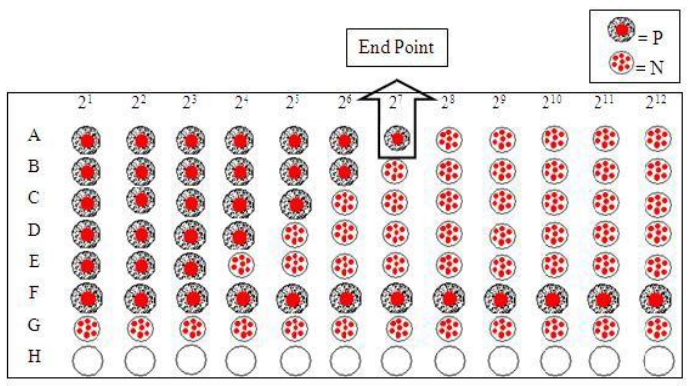

Gambar 2. Notasi End Point HI Test (P: Kontrol Positif/Inhibisi; N: Kontrol Negatif)

Gambar 3. Persawahan di sekitar CAPD. Kiri: unggas domestik mencari makan,. Kanan: burung air liar yang berkeliaran mencari makan di tambak yang sama dengan tempat ungags domestik mencari makan (Sumber: Bustami, 2011)
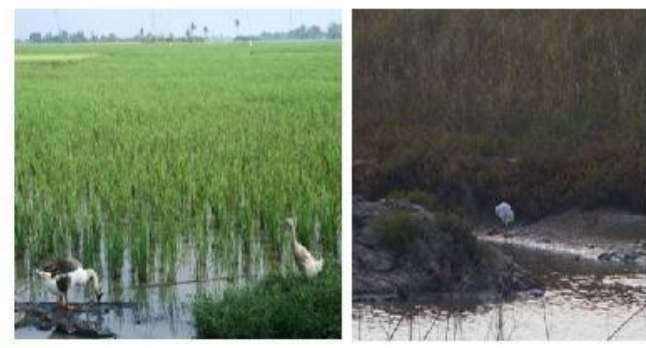

Tidak timbulnya gejala klinis infeksi AI pada hewan uji diperkirakan karena ungags domestik terpapar sedikit demi sedikit sehingga paparan ini mampu menstimulasi timbulnya antibodi anti H5N1 tetapi tidak cukup untuk menimbulkan gejala secara klinis (Subbarao \& Katz, 2000). Penelitian sebelumnya yang dilakukan oleh Kurniawati (2011) dan Bustami (2011) pada burung air liar di kawasan CAPD menunjukkan nilai titer antibodi H5N1 yang jauh lebih rendah dari titer antibodi pada ayam, itik dan mentok. Titer antibodi burung air liar tersebut yaitu $2^{0,583}$ pada burung Kuntul Besar, 20,286 Kuntul Sedang, 20,32 Kuntul Kecil dan 20,28 Kowak 
Malam.

Nilai titer yang tinggi pada unggas domestik mengindikasikan bahwa unggas tersebut terpapar virus secara terus-menerus. Hal ini menjelaskan bahwa sumber virus AI berasal dari unggas domestik dan pola penularan yang terjadi adalah dari unggas domestik ke burung air liar. Nilai titer yang rendah pada burung air liar mengindikasikan bahwa burung-burung tersebut hanya sesekali terpapar virus AI, yaitu pada saat mencari makan di tambak atau sawah. Burung air liar dapat terinfeksi virus AI subtipe H5N1 dari unggas domestik saat melakukan kontak dengan permukaan atau materi di lahan basah tempat mereka bersama-sama mencari makan (Monke \& Corn 2007). Virus AI subtipe H5N1 mampu bertahan hidup di air dalam kurun waktu empat hari pada kisaran suhu $22^{\circ} \mathrm{C}$ (Aditya, 2007).

Unggas domestik yang dipelihara warga umumnya keluar kandang pada siang hari dan berkeliaran di daerah sawah dan tambak yang juga menjadi salah satu tempat mencari makan bagi burung air liar di kawasan CAPD (Gambar 3). Jarak antara pemukiman penduduk dari habitat burung liar di kawasan CAPD hanya 500 meter (Bustami, 2011).

Siklus penularan tidak langsung dapat terjadi melalui rantai makanan yang tercemar virus $\mathrm{AI}$ dari feses ke mulut atau dari mulut ke feses (Nazarudin 2008 in Kurniawati 2011). Ayam peliharaan masyarakat di sekitar kawasan CAPD biasa meminum air di kubangan air bersama-sama dengan burung air liar (Kurniawati, 2011). Berdasarkan observasi yang telah dilakukan oleh Ramirez et al. (2004) pada air minum di kandang itik yang terinfeksi, menunjukkan adanya virus dalam jumlah tinggi yang menyebabkan terjadinya penularan.

Kontaminasi virus Avian Influenza terjadi pada air permukaan (kolam, sungai, danau), air tanah, dan tampungan air hujan. Keseluruhan sumber air tersebut mempunyai potensi lebih tinggi terkontaminasi virus Avian Influenza. Faktorfaktor yang mempengaruhi keberlangsungan virus di air sangat tergantung pada suhu, $\mathrm{pH}$ dan salinitas. Umumnya viabilitas virus Avian Influenza menurun jika salinitas meningkat dan $\mathrm{pH}$ di bawah netral (WHO, 2006).
Penyebaran VAI dalam kelompok ternak unggas tergantung bentuk pemeliharaannya. Pada kelompok yang dilepas di tempat kotor dan terjadi hubungan langsung serta percampuran dengan hewan lain, penyebaran virus akan berlangsung lebih cepat daripada yang dipelihara dalam kandang. Penularan sempurna dapat terjadi dalam beberapa hari (Kamps et al.,2006).

Highly Pathogenic Avian Influenza Virus H5N1 telah menyebabkan kematian dalam jumlah besar pada burung liar. Namun hasil surveilans intensif yang dilakukan di Eropa, Amerika Utara, Asia dan Afrika mencakup 750.000 sampel menunjukkan sangat sedikit burung air liar sehat yang ditemukan menyimpan virus H5N1 (FAO, OIE \& WHO, 2011). Hal ini sejalan dengan hasil penelitian Kurniawati (2011) dan Bustami (2011) pada burung air liar di kawasan CAPD yang menunjukkan seroprevalensi rendah, yaitu hanya $8,8 \%$ pada ketiga spesies kuntul dan 10,7\% pada kowak malam. Seroprevalensi sebesar $100 \%$ yang diperoleh pada penelitian ini menunjukkan bahwa semua sampel unggas domestik di sekitar CAPD telah terpapar virus AI subtipe H5N1 (Tabel 1). Hal ini mendukung dugaan bahwa sumber penularan virus AI adalah unggas domestik.

Penelitian yang dilakukan Susanti et al. (2008) menunjukkan bahwa isolat virus AI dari unggas air (itik, mentok dan angsa) yang belum divaksinasi dan tidak menunjukkan gejala klinis pada peternakan skala kecil di Jawa Barat merupakan H5N1 strain HPAIV (highly pathogenic). Unggas air diduga berperan sebagai reservoir HPAIV H5N1. Unggas air yang merupakan reservoir alami virus AI, memberi peluang yang besar terhadap bermunculannya berbagai sub-tipe dari kombinasi HA dan NA saat replikasi virus di saluran pencernaannya (Animal Health Australia 2011).

Ayam menunjukkan titer HI tertinggi karena ayam memiliki sensitivitas tinggi terhadap protein asing, sehingga keterpaparan dalam jumlah sedikit dapat membangkitkan respon pembentukan antibodi (Yusran 2008). Lee (2005) juga 
membuktikan bahwa titer antibodi pada itik lebih rendah dibandingkan pada ayam dan burung puyuh. Hasil studi ini sesuai dengan hasil investigasi Balai Besar Veteriner (BBVet) dan beberapa survei epidemiologi dan epidemiologi molekuler yang menunjukan bahwa tingkat prevalensi virus $\mathrm{H} 5 \mathrm{~N} 1$ clade 2.1 pada itik dan unggas air lainnya di Indonesia sangat rendah dibandingkan prevalensi virus pada ayam (Wibawa et al., 2012). Di Indonesia memang tidak dilakukan vaksinasi HPAIV H5N1 pada itik karena patogenitas virus ini yang sangat rendah pada itik (FAO 2011).

Rendahnya patogenitas HPAI subtipe H5N1 pada unggas air (mentok dan itik) dibandingkan ayam disebabkan pada unggas air jumlah enzim proteolisis lebih sedikit dibandingkan pada ayam. Paparan VAI pada ayam akan menyebabkan timbulnya gejala klinis yang cukup berarti, bahkan mungkin sekali menyebabkan kematian. Enzim proteolisis tersebut berfungsi untuk memecah prekursor hemaglutinin pada amplop virus dari bentuk inaktif menjadi aktif (Aditya, 2007).

Pada sistem peternakan pekarangan, unggasunggas saling berinteraksi secara bebas. Kondisi ini dapat meningkatkan resiko paparan VAI. Sistem peternakan pekarangan ini merupakan penyebab tingginya titer antibodi unggas domestik sebab keterpaparan terjadi secara terus- menerus dalam waktu yang lama. Hal ini berkorelasi dengan penelitian yang dilakukan Suardana et al. (2009) yang menunjukkan bahwa proses vaksinasi virus inaktif $\mathrm{H} 5 \mathrm{~N} 1$ pada serum itik akan memperlihatkan titer antibodi hingga 3,8 kali lebih tinggi pada vaksinasi kedua. Hewan yang baru saja terpapar virus akan menunjukkan nilai titer yang rendah, karena jumlah virus masih sedikit sehingga hewan tidak mampu menghasilkan antibodi dalam jumlah yang cukup tinggi (Aditya, 2007).

Tingginya seroprevalensi dan titer antibodi pada unggas domestik (ayam, itik dan mentok) pekarangan milik penduduk di kawasan sekitar CAPD menunjukkan bahwa daerah ini telah endemis VAI subtipe H5N1. Pemeliharaan sistem pekarangan dengan biosecurity yang rendah merupakan kendala penanganan VAI di Asia, termasuk Indonesia (WHO, 2005). Biosecurity adalah strategi dan pendekatan yang terintegrasi untuk proses analisa dan pengaturan resiko kontaminasi penyakit pada manusia, hewan, tumbuh-tumbuhan serta dampak yang ditimbulkan terhadap lingkungan (INFOSAN, 2010). Sebanyak 10.000 ekor itik yang dipelihara dalam kandang tertutup dengan tingkat biosecurity yang tinggi, tidak satupun terinfeksi VAI subtipe H5N1 baik secara serologis maupun biologis. Itik pekarangan menunjukkan tingkat prevalensi VAI paling tinggi (47\%) dibanding itik yang digembalakan di ladang pertanian $(45,9 \%)$ dan itik yang dipelihara dalam kandang terbuka $(23,5 \%)$ (Songserm et al.,2006 in Susanti et al., 2009).

Biosecurity berperan sangat penting terhadap pencegahan wabah H5N1 pada peternakan unggas. Kegiatan biosecurity bertujuan untuk mencegah kontak antara burung liar dengan unggas domestik dan membatasi akses manusia yang tidak berkepentingan ke dalam area peternakan. Jenis-jenis kegiatan biosecurity antara lain kendaraan pengangkut unggas dan pegawai peternakan harus bersih dan disucihamakan sebelum memasuki area atau saat berpindah dari kandang ke gudang dan sebaliknya (Monke\&Corn, 2007). Prosedur biosecurity yang dapat diaplikasikan untuk mencegah penularan VAI subtipe H5N1 antara lain, pemberlakuan vaksinasi bagi hewan ternak, penggunaan pakaian khusus (sepatu boot dan jas) serta cairan antiseptik bagi orangorang yang keluar atau masuk area peternakan, bangunan kandang yang tertutup dan sesuai standar keamanan, tidak memindahkan kotoran ternak keluar area peternakan dan secara rutin melakukan pembersihan kandang dengan cairan desinfektan (Ausvetplan, 2011).

Faktor-faktor lain yang juga berpengaruh nyata terhadap penurunan seropositif VAI yaitu pembersihan kandang dengan desinfektan dan keberadaan pekerja kandang yang lebih dari 1 orang dibanding tanpa pekerja kandang (Woo\&Park, 2008). Pada unggas penelitian yang dipelihara dengan sistem pekarangan, prosedur biosecurity kurang diterapkan oleh peternak. Unggas bebas berkeliaran dan mencari makan di sekitar halaman rumah 
warga. Pembersihan kandang juga tidak dilakukan secara rutin atau bahkan tidak pernah dilakukan. Tidak diterapkannya prosedur biosecurity ini menyebabkan penularan penyakit antar unggas sangat mudah terjadi.

\section{PENUTUP}

\section{Kesimpulan}

Dari penelitian ini didapatkan kesimpulan sebagai berikut:

1. Serologi dari ketiga spesies unggas domestik (ayam Gallus gallus domestikus, itik Anas sp dan mentok Cairina moschata) adalah $100 \%$.

2. Rataan titer antibodi untuk masing-masing spesies adalah $2^{7,7}$ untuk ayam Gallus gallus domesticus; 27,9 untuk mentok Cairina moschata dan 24,6 untuk itik Anas sp.

\section{Saran}

1. Perlu dilakukan penelitian karakterisasi patogenitas virus Avian Influenza subtipe H5N1 yang berasal dari isolat pada unggas domestik dan burung air liar di kawasan Cagar Alam Pulau Dua baik secara molekuler maupun biologis.

2. Peternakan unggas domestik skala rumah tangga disarankan untuk melakukan tindakan- tindakan pencegahan seperti membuat kandang unggas, sanitasi kandang serta vaksinasi unggas untuk minimalisasi penyebaran virus Avian Influenza subtipe H5N1.

\section{DAFTAR PUSTAKA}

[1] Aditya IG. 2007. Prevalensi Serologi Avian Influenza pada Unggas Sektor IV di Desa Pasawahan Kecamatan Cicurug Kabupaten Sukabumi [skripsi]. Bogor: Fakultas Kedokteran Hewan, Institut Pertanian Bogor. Bogor.

[2] Akoso BT. 2006. Waspada Avian Influenza. Penyakit Menular Pada Hewan dan Manusia. Kanisius: Yogyakarta.

[3] Anies. 2005. Cegah Avian Influenza pada Manusia. www.suara merdeka.com/harian/0507/3/opi04.htm. (Diakses Pada 12_April 2014)

[4] Animal Health Australia. 2011. Disease strategy: Avian Influenza (Version 3.4). Australian Veterinary Emergency Plan
(AUSVETPLAN), Edition 3.

[5] Primary Industries Ministerial Council, ACT: Canberra.

[6] Ausvetplan. 2011. Disease Strategy - Avian Influenza version 3.4, 2011. Primary Industries Ministerial Council - Australian Veterinary Emergency Plan.

[7] Bustami E. 2011. Seroprevalensi Avian Influenzasubtipe H5N1 pada Nycticorax nycticorax di Kawasan Cagar Alam Pulau Dua [Skripsi]. Jakarta: Fakultas Sains dan Teknologi, Universitas Al Azhar Indonesia. Jakarta.

[8] Capua I, Mutinelli F. low pathogenicity (LPAI) and highly pathogenic (HPAI) Avian Influenzain turkeys and chicken. Di dalam: Capua I, Mutinelli F. (eds.). A Colour Atlas and Text on Avian Influenza. Papi Editore. Bologna. 2001. Pp. 13-20.

[9] [Disbudpar]Dinas Kebudayaan dan Pariwisata BantenCagar Alam Pulau Dua/Pulau Burung. http://bantenculturetourism.co $m / ? p=358$. (Diakses pada 02 Mei 2012).

[10] [Ditennak] Direktorat Jenderal Peternakan. Perkembangan Situasi kasus AI pada Unggas di Indonesia. http://ditjennak.deptan.go.id/index.ph p? page $=$ berita\&action $=$ detail $\&$ idber $i$ $t a=312$ (Diakses pada 02 Mei 2012).

[11] Elfidasari D. 2013. Potensi Burung Air Liar Terhadap Penyebaran Virus Avian InfluenzaSubtipe H5N1 di cagar Alam Pulau Dua [Disertasi]. Bogor: Sekolah Pasca Sarjana, Institut Pertanian Bogor.Bogor.

[12] European Commission. 2000. The Definition of Avian Influenza - The use of Vaccination AgainstAvian Influenza. European Commission Health \& Consumer Protection Directorate - General - Sanco.

[13] FAO. 2008. Burung liar dan Avian Influenza: Pengantar riset lapangan terapan dan tehnik pengambilan sampel penyakit. Di dalam: Whitworth D, Newman SH, Mundkur T, Harris P. Panduan Produksidan Kesehatan Hewan 
FAO, No. 5. Food and Agriculture Organization of the United Nations \& WetlandsInternational - Indonesia Programme, Jakarta: United Nations \& Wetlands International.

[14] FAO. 2011. H5N1 HPAI: Global overview, April-June 2011. EMPRES/FAO-GLEWS, Issue No.28. www.fao.org/avianflu/en/over view.htm. (Diakses Pada 02 Mei 2012)

[15] FAO-OIE-WHO. 2011. FAO-OIEWHO Technical Update: Current Evolution of Avian Influenza H5N1 Virus. http://www.fao.org/docrep/014/a1873e00.pd $f$ (Diakses Pada 02 Mei 2012).

[16] Fouchier RA, Olsen B, Bestebroer TM. 2003. Influenza A virus surveillance in wild birds in Northern Europe in 1999 and 2000. Avian Dis 47: 857.

[17] Hadipour MM, Habibi G, Vosoughi.2011. Prevalence of Antibodies to H9N2 AIV in Backyard Chickens Around Maharlou Lake in Iran. Pakistan Veterinary Journal 31(3):192-194.

[18] INFOSAN.2010. Biosecurity: An Inegrated Approach to Manage Risk to Human, Animal, and Plant Life and Health. INFOSAN Information Note 2010 (1). www.who.int/foodsafety/fs/NoO1 Biosecurity Mar10 en.pdf. (Diakses Pada 9 Juli 2014).

[19] Jin M, Wang G, Zhang R, Zhao S, Li H, Tan Y, Chen H.. Development of enzymelinkedimmunosorbent assay with nucleoprotein as antigen for detection of antibodies to Avian Influenza virus. Avian Dis. 2004; 48: 870-8 Abstract: http://amedeo.com/lit.php?id=15666868

[20] Kamps S, Hoffman C, Preiser W.2006. Influenza report 2006. Flying Publisher: Paris, Cagliari, Wuppertal, Sevilla.

[21] Katz J, Hancock K, Veguilla V, Zhong W, Lu XH, Sun H, Butler E, Dong L, Liu F, Li ZN, Devos J, Gargiullo P, Cox N. 2009. Serum Cross-Reactive Antibody Response to a Novel Influenza A(H1N1) Virus After Vaccination with Seasonal Influenza Vaccine. Morbidity and Mortality Weekly ReportMor MWRep58(19):521-524.

[22] Kim HR. 2012. Highly Pathogenic Avian Influenza (H5N1) Outbreaks in Wild Birds and Poultry, South Korea. Emergancy Infection Diseases 18(3):480-483.

[23] Kurniadhi P, Suparno. 2009. Teknik Pengambilan Sampel Dari Burung Air LiarUntuk Pengujian Penyakit Flu Burung.
Buletin Teknik Pertanian. 14 (2): 83-86

[24] Kurniawati LM. 2011. Seroprevalensi Virus Avian Influenza H5N1 pada Ketiga Spesies Burung Kuntul (Casmerodius albus, Egretta intermedia dan E. garzetta) di Kawasan Cagar Alam Pulau Dua Serang, Banten [Skripsi]. Jakarta:Fakultas Sains dan Teknologi, Universitas Al Azhar Indonesia. Jakarta.

[25] Lee CW. 2005. Characterization of Highly Pathogenic H5N1 Avian Influenza A Viruses Isolated from South Korea.JViral79(6):3692-3702.

[26] Monke J, Corn ML. 2007. CRS Report for Congress: Avian Influenza in Poultry and Wild Birds. Congressional Research Services.

[27] [OIE] World Organization of Animal Health. 2009. Avian Influenza. Di dalam: World Assembly of Delegates of The OIE; Mei 2009. OIE Terrestrial Manual 2009.

[28] Radji M. 2006. Avian InfluenzaA (H5N1): Patogenesis, Pencegahan dan Penyebaran pada Manusia. Majalah Ilmu Kefarmasian 3(2):5565.

[29] Ramirez KMS, Ellis T, Bousfiels B, Bissett L, Dyrting K, Rehg JE, Poon L, Guan Y, Peiris M, Webster RG. 2004. Reemerging H5N1 Influenza Viruses in Hong Kong in 2002 Are Highly Pathogenic to Duck. J. Virol. 78(9):4892-4901

[30] Stephenson I, Alan H, Diane M, Robert WN, Katja H, Wang J, Jacqueline MK, Jerry PW, Maria CZ, John MW. 2009.Reproducibility of Serologic Assays for Influenza Virus A (H5N1). EID J 15(8).

[31] Suardana IBK, Ni MRKD, Gusti NKM. 2009. Respon Imun Itik Bali Terhadap Berbagai Dosis Vaksin Avian Influenza H5N1. J. Vet 10(3):150-155.

[32] Subbarao K,Katz J. 2000. Avian Influenza Infecting Humans (Review). Cell Molecular Life Sci.57:1770-84.

[33] Susanti R, Soejoedono RD, Mahardika IGNK, Wibawan IWT, Suhartono MT. 2008. Identificaton 
of Pathogenicity of Avian Influenza Virus subtype H5N1 from Waterfowls Based on Amino Acid Sequence of Cleavage Site Hemaglutinin Protein.Indonesian J. Biotech13(2):1069-1077.

[34] Susanti R, Soejoedono RD, Mahardika IGNK, Wibawan IWT, Suhartono MT. 2009. Isolasi dan Identifikasi Virus Avian Influenza Subtipe H5N1 pada Unggas Air Sehat di Peternakan Skala Rumah Tangga di Jawa Barat. Media Kedokteran Hewan 24(3):139-145.

[35] Swayne DE, Suarez DL. Highly pathogenic Avian Influenza. Rev Sci Tech 2000; 19: 463-8.Abstract : http://amedeo.com/lit.php?id= 10935274

[36] Webster RG, Bean WJ, Gorman OT, Chambers TM, Kawaoka Y. 1992. Evolution and ecology of influenza A viruses. Microbial V 56:152-79.

[37] Whithnorth D, Newman S, Mundhur T, Harris P. 2008. Burung Liar dan Avian Influenza - Pengantar Riset Lapangan Terapan dan Teknik Pengambilan Contoh Penyakit. FAO - Wetlands International.

[38] WHO. 2005. Evolution of H5N1 Avian Influenza Viruses in Asia. The World Health Organization Global Influenza Program Surveillance Network. Emer. Inf. Dis 11(10): 1515-1520.

[39] WHO. 2006. Questions and Answers on Avian Influenza a Selection of Frequently Asked Questions on Animals, Food and Water. WHO: Geneva.

[40] WHO.2011. Cumulative Number of Confirmed Human Cases for Avian InfluenzaA(H5N1) reported to WHO, 20032011.

[41] Wibawa H, Walujo PJ, Niluh PID, Sri HI, Yuli M, Anieka R, Erness A, Romlah, Rosmalina SDD, Kiki S. 2012.Investigasi Wabah Penyakit pada Itik di Jawa
Tengah, Yogyakarta dan Jawa Timur: Identifikasi Sebuah Clade Baru Virus Avian Infuenza Subtipe H5N1 di Indonesia. Bul. Lab. Vet (12) 4: 29.

[42] Wibowo AA, Susanti R, Ulum F, Nugrahaningsih WH. 201. Isolasi dan Identifikasi Virus Avian Influenza Subtipe H5N1 di Peternakan Tradisional Kecamatan Gunungpati Semarang. Biosantifika 4(2):62-70. Widjaja L, Krauss SL, Webby RJ, Xie T, Webster RG. 2004. Matrix geneinfluenza isolated from wild aquatic birds: ecology and emergence of influenza a viruses. $J$ Virol 78: 8771-9.

[43] Wihardandi A. 2014. Tag Achieves: Migrasi Burung, Pengamatan Burung Air, Langkah Awal Lindungi Habitat Lahan Basah. www.mongabay.co.id/ tag/migrasi-burung/. (Diakses Pada 12 Maret 2014).

[44] Winarno. 2008. Mengantisipasi penyakit flu burung.www.depan.go.id/daerah_new /banten/dispertanak pandeglang/artik el_16.htm. (Diakses Pada 10 Februari 2014).

[45] Woo JT, Park BK.2008. Seroprevalence of LPAIV (H9N2) and associated risk factor in the Gyeonggi-do of Korea during 20052006. J. Vet. Sce 9(2):161-168.

[46] Yusran WO. 2008. Gambaran Titer Antibodi Anti H5 pada Serum dan Kuning Telur Ayam Single Comb Brown Leghorn yang Divaksinasi dengan Vaksin Inaktif H5N2 [Skripsi]. Bogor: Fakultas Kedokteran Hewan, Institut Pertanian Bogor. Bogor. 